\title{
THE EVALUATION OF ONLINE PERSUASION CRITERIA ON E-COMMERCE WEBSITE USING PERSUASIVE SYSTEM DESIGN (PSD) MODEL
}

\author{
Yin-Xia Loh* \\ Faculty of Technology Management and Business, Universiti Tun Hussein Onn Malaysia \\ (UTHM) \\ Faculty of Accountancy and Management, Universiti Tunku Abdul Rahman (UTAR) \\ Nor Aziati Binti Abdul Hamid \\ Faculty of Technology Management and Business, Universiti Tun Hussein Onn Malaysia \\ (UTHM)
}

\begin{abstract}
Persuasive technology in online shopping is proven to assist people while purchasing online. It is crucial to study how was the implementation of such successful persuasive technology in the e-commerce domain. Also, there are certain marketing strategies against consumers from different generational cohorts. Each generation has unique lifestyles, generational history, demographics, experiences, expectations and values that influence their buying behaviours. The persuasive design of e-commerce websites is related to the website conversion rate and is shown to support people throughout the online purchasing process. The objective of this research study is to evaluate the online persuasion criteria on two largest e-commerce websites in Malaysia; Lazada and Shopee through Persuasive System Design (PSD) principles. The four main categories of design technique applied in PSD are primary task support, dialogue support, credibility support and social support. The result shows that both selected e-commerce websites have applied $71.43 \%$ of the PSD principles. The most emphasize design technique in Lazada and Shopee is primary task support, followed by dialogue support. Most of the persuasive features in this model has implemented in both e-commerce websites. However, this research proved that the success of the e-commerce websites is related with the implemented persuasive feature which can be manipulated and implemented by other e-commerce websites.
\end{abstract}

Keywords: Persuasive Technology, Persuasive System Design (PSD), E-Commerce, Website Design.

Received: 17 May 2020

Accepted: 31 July 2021

https://doi.org/10.33736/ijbs.4289.2021

\section{INTRODUCTION}

Persuasive means invent to influence, a process aimed to change a person's beliefs or behaviour, to adopt the position, or to consider the arguments provided (Gass \& Seiter, 2011). The rapid growth in World Wide Web (www), Internet, Smart Phone, and other technologies enhance user's reachability and create great opportunities for persuasive interaction. Back to 1990 where the Web was first launched by the inventor of the Web, Sir Tim Berners-Lee (Connolly, 2000). Until the

\footnotetext{
* Corresponding author: University Tun Hussein Onn Malaysia, 86400 Parit Raja, Batu Pahat, Johor, Malaysia; Universiti Tunku Abdul Rahman, 43000, Kajang, Selangor, Malaysia. H/Phone: +6011-11886680; Email: yxloh@outlook.com
} 
end of 1993, the web is still unpopular. Initially, there were only 50 Web servers in existence (Connolly, 2000). The number of Web servers then rose 10 times to approximately 500, showing how fast the Web developed in 1993 (Raggett et al., 1996). Globalization has turned the World Wide Web into one of the mainstream media in modern society as it allows instant access to various sources of information (Wolf, 2014). In the past, people can only get the information from newspaper, radio or TV. Nowadays, with the Web, people can instantly get the news update, weather forecasts through internet. World Wide Web (WWW) has become the key components of both everyday social life and the business world.

These days building a business website or e-commerce store is easier than ever. From small local business to leading entities in this new technology era, having a website is not an option but necessity for their business growth. One can simply search a website online through few simple keywords. For instance, even Facebook, Google and Amazon have built their very own official website to publish the company mission and update latest news. While having an e-commerce website isn't just about online businesses; it also providing valuable content to attract potential customers and having interactions with users. This is where persuasive features come in and play it role. Subsequently, persuasive design of the website lead users to adopt and continue to revisit these websites, as well as to buy more products or services.

Recent years, e-commerce is taking off in Malaysia with the growth rate at about $6 \%$ per year (Department of Statistics Malaysia, 2019). As one of the highest internet penetrations country in Southeast Asia (81.2\%), Malaysia has become one of the fastest growing e-commerce markets in the region. In this context, e-commerce in Malaysia presents as a mature platform for persuasive tools. With the aim to improve their overall quality through emphasizing website credibility and improving marketing strategies, many persuasive features were extensively applied in the design of e-commerce websites (Fogg et al., 2003, Kaptein \& Duplinsky, 2013). As the first contact point when users shop online, it is crucial for the e-commerce websites appeal attractive to the visitor. The products on the e-commerce websites need to be presented in the most attractive manner, gaining user attention to check out the sales and promotions event, similar products suggestions, and finally complete the purchase process (Winn \& Beck, 2002).

The study aimed to evaluate the online persuasion criteria applied to the successful e-commerce websites in Malaysia. The persuasive design of e-commerce websites is related to the website conversion rate and is shown to support people throughout the online purchasing process. It was built on top of changing or shaping users' behaviour to retain users and increase the number of closed deals. The importance of e-commerce websites persuasiveness has been proven through prior studies. Findings from previous studies imply that persuasive design features have been widely applied in the successful e-commerce websites such as Amazon, eBay (Alhammad \& Gulliver, 2014), and Zalora (Abdul Hamid et al., 2019).

\section{LITERATURE REVIEW}

\subsection{Persuasive System Design Model (PSD)}

The rising expectations for persuasive designs are evident in the competitive markets like the Web 2.0, the e-commerce and the mobile domain. Due to the rapid pace of persuasive technology growth, 
designers required a comprehensive knowledge about various types of persuasion strategies. There is where the Persuasive System Design Model comes in. This model is especially useful for designers without strong theoretical background regarding persuasion domain.

Persuasive System Design (PSD) Model defines to use persuasion in the websites in terms of design. Oinas-Kukkonen and Harjumaa have invented the PSD model used to design and evaluate persuasive systems in a systematic way (Oinas-Kukkonen, \& Harjumaa, 2008). As a meta-level model, PSD model is designed to be used together with behavior or attitude change theories, such as Fogg's Behavior Model (Fogg, 1998), the Theory of Reasoned Action (Fishbein, \& Ajzen, 1977), the Theory of Planned Behavior (Ajzen, 1991), Social Cognitive Theory Locke, (Locke, 1987), the Elaboration Likelihood Model (Petty \& Cacioppo, 1981) or other suitable theories. Seven postulates to be addressed when designing or evaluating persuasive systems were defined (Altmeyer et al., 2019). The seven postulates have been further described as the core components in a later study (Oinas-Kukkonen, \& Harjumaa, 2009). The seven core components of the PSD model are illustrated in Figure 1, where two related to users, two related to persuasion strategies and three related to actual system features.

Figure 1: Core components of the PSD model

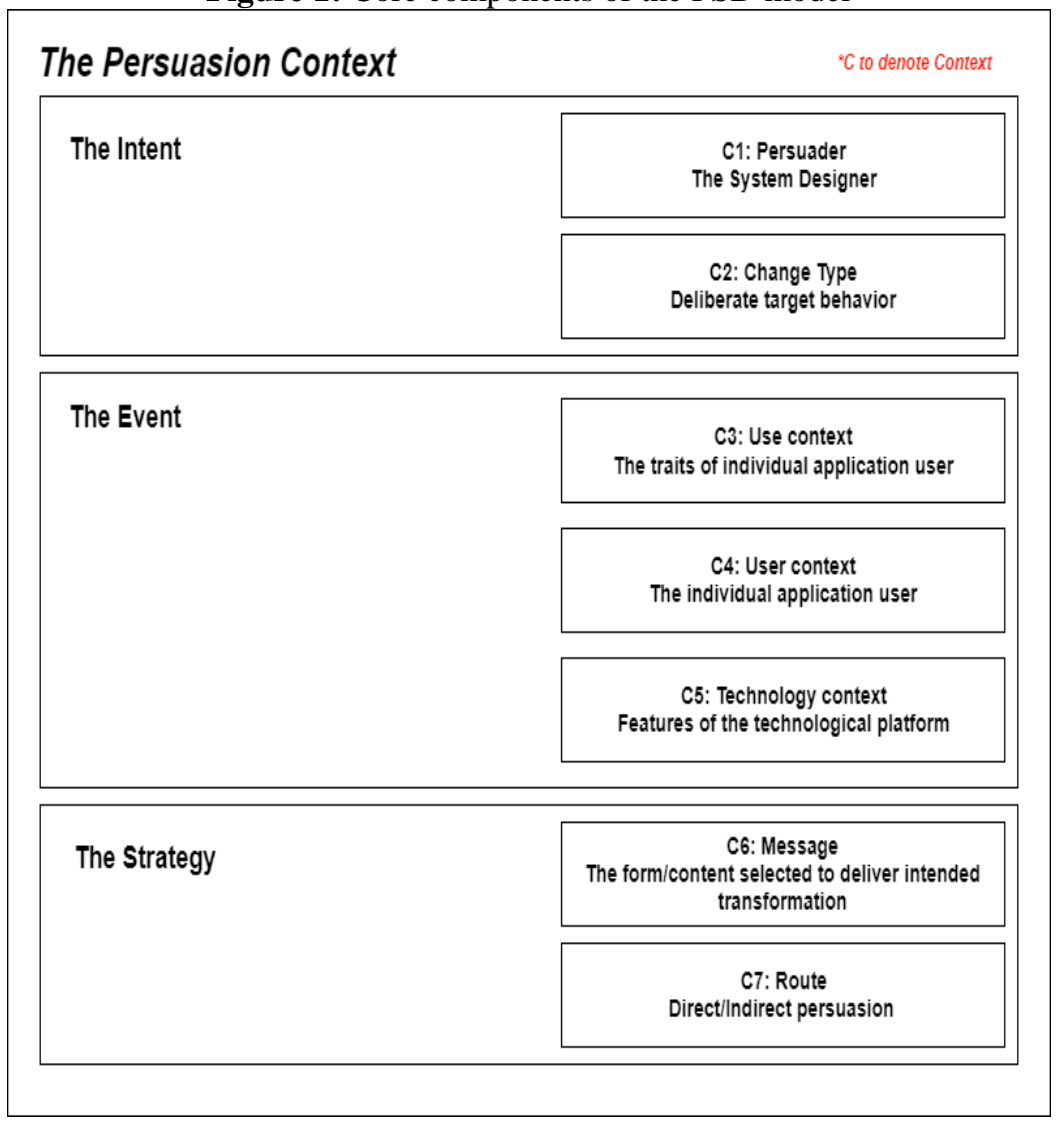


In addition to Fogg's functional triad and its design principles, PSD model has categorized four persuasive system features: primary task support, dialogue support, system credibility support, and social support (Oduor \& Oinas-Kukkonen, 2019). Table 1 shows all the elements in four persuasive system features.

Table 1: PSD System Features and Design Element

\begin{tabular}{|c|c|c|c|}
\hline Category & $\begin{array}{l}\text { Design } \\
\text { Technique }\end{array}$ & Description & References \\
\hline \multirow{7}{*}{$\begin{array}{l}\text { Primary } \\
\text { Task } \\
\text { Support }\end{array}$} & Reduction & $\begin{array}{l}\text { Making actions effortless, making } \\
\text { information as simple as possible }\end{array}$ & $\begin{array}{l}\text { Radomski et al. } \\
(2019)\end{array}$ \\
\hline & Tunnelling & $\begin{array}{l}\text { Guiding users through a prearranged } \\
\text { sequence of actions or events }\end{array}$ & Win et al. (2017) \\
\hline & Tailoring & $\begin{array}{l}\text { Customizing actions or information to user } \\
\text { needs and characteristics }\end{array}$ & Aldenaini et al. (2020) \\
\hline & Personalization & $\begin{array}{l}\text { Offers personalized content or services has a } \\
\text { greater capability for persuasion }\end{array}$ & $\begin{array}{l}\text { Oduor \& Oinas- } \\
\text { Kukkonen (2019) }\end{array}$ \\
\hline & Self-monitoring & $\begin{array}{l}\text { Helps users to track their own performance or } \\
\text { status will supports in achieving goals }\end{array}$ & $\begin{array}{l}\text { Lehto \& Oinas- } \\
\text { Kukkonen (2015) }\end{array}$ \\
\hline & Simulation & $\begin{array}{l}\text { Persuade by enabling users to observe } \\
\text { immediately the link between the cause and } \\
\text { its effect }\end{array}$ & Win et al. (2018) \\
\hline & Rehearsal & $\begin{array}{l}\text { Rehearse a behaviour can persuade people to } \\
\text { change their attitudes or behaviour in the real } \\
\text { world }\end{array}$ & $\begin{array}{l}\text { Oduor \& Oinas- } \\
\text { Kukkonen (2019) }\end{array}$ \\
\hline \multirow[t]{7}{*}{$\begin{array}{l}\text { Dialogue } \\
\text { Support }\end{array}$} & Praise & $\begin{array}{l}\text { Provide positive feedback to users through } \\
\text { different forms, such as text message, images } \\
\text { or sound }\end{array}$ & Adaji et al. (2019) \\
\hline & Rewards & $\begin{array}{l}\text { Offer users some reward like instant rebate or } \\
\text { vouchers for performing target behaviour }\end{array}$ & $\begin{array}{l}\text { Oduor \& Oinas- } \\
\text { Kukkonen (2019) }\end{array}$ \\
\hline & Reminders & $\begin{array}{l}\text { Reminds the users of target behaviour during } \\
\text { the use of the websites }\end{array}$ & $\begin{array}{l}\text { Lehto \& Oinas- } \\
\text { Kukkonen (2015) }\end{array}$ \\
\hline & Suggestion & $\begin{array}{l}\text { Suggests products or services that users may } \\
\text { interested at the opportune moment }\end{array}$ & Win et al. (2017) \\
\hline & Similarity & $\begin{array}{l}\text { Websites imitates its users in specific and } \\
\text { meaningful way, for example, by using users' } \\
\text { own language or currency }\end{array}$ & $\begin{array}{l}\text { Oduor \& Oinas- } \\
\text { Kukkonen (2019) }\end{array}$ \\
\hline & Liking & $\begin{array}{l}\text { Websites should have a look and feel that is } \\
\text { visually attractive and appeals to its users }\end{array}$ & Win et al. (2017) \\
\hline & Social role & Websites adopts a role of social actor & Adaji et al. (2019) \\
\hline \multirow{5}{*}{$\begin{array}{l}\text { System } \\
\text { Credibility } \\
\text { Support }\end{array}$} & Trustworthiness & $\begin{array}{l}\text { The information or services provided on the } \\
\text { website should be truthful, fair and unbiased }\end{array}$ & Matthews et al. (2016) \\
\hline & Expertise & $\begin{array}{l}\text { Provided professional information, } \\
\text { knowledge, experience and competence that } \\
\text { showing expertise }\end{array}$ & Win et al. (2017) \\
\hline & $\begin{array}{l}\text { Surface } \\
\text { credibility }\end{array}$ & Website should have competent look and feel & Matthews et al. (2016) \\
\hline & Real-world feel & $\begin{array}{l}\text { Website should indicate information about } \\
\text { organization providing the service }\end{array}$ & $\begin{array}{l}\text { Oduor \& Oinas- } \\
\text { Kukkonen (2019) }\end{array}$ \\
\hline & Authority & Website refer to organization or people in the & Aldenaini et al. (2020) \\
\hline
\end{tabular}




\begin{tabular}{|c|c|c|}
\hline & & role of authority \\
\hline & $\begin{array}{l}\text { Third-party } \\
\text { endorsements }\end{array}$ & $\begin{array}{l}\begin{array}{l}\text { Provided endorsements from respected Matthews et al. (2016) } \\
\text { sources }\end{array} \\
\end{array}$ \\
\hline & Verifiability & $\begin{array}{ll}\begin{array}{l}\text { Provide means to identify the accuracy of site } \\
\text { content through external sources }\end{array} & \text { Kukkonen }(2015)\end{array}$ \\
\hline \multirow[t]{6}{*}{$\begin{array}{l}\text { Social } \\
\text { Support }\end{array}$} & Social Learning & $\begin{array}{ll}\begin{array}{l}\text { Allow users to observe another customers' } \\
\text { behaviour outcome }\end{array} & \begin{array}{l}\text { Oduor \& Oinas- } \\
\text { Kukkonen }(2019)\end{array} \\
\end{array}$ \\
\hline & $\begin{array}{l}\text { Social } \\
\text { Comparison }\end{array}$ & $\begin{array}{l}\text { Allow users to compare their own Matthews et al. (2016) } \\
\text { performance with other customers }\end{array}$ \\
\hline & $\begin{array}{l}\text { Normative } \\
\text { influence }\end{array}$ & $\begin{array}{l}\text { Provide means for gathering people who have Adaji et al. (2019) } \\
\text { the same goal and get them to feel norms }\end{array}$ \\
\hline & Social facilitation & $\begin{array}{l}\text { Allow users to differentiate other users who Aldenaini et al. (2020) } \\
\text { behave the same as them }\end{array}$ \\
\hline & Cooperation & $\begin{array}{ll}\text { Provide means for users to co-operate } & \text { Oduor \& Oinas- } \\
& \text { Kukkonen (2019) }\end{array}$ \\
\hline & Competition & Provide means for users to compete \\
\hline
\end{tabular}

\subsection{Web Design Principles}

Globalization has turned the World Wide Web into one of the mainstream media in modern society. A nicely designed website is not only about the visual appeal but also focus on content quality and usability. Lacking in any aspect could result in demolishing nice impression for website users. These aesthetic and design features are associated with conversion rate and convert e-commerce visitors into purchasers (McDowell et al., 2016). A successful website is the product of a combination of interesting content, high usability and aesthetic design (Thielsch et al., 2014). In digital shopping environment, it is crucial for the designer to determine the right balance between visual and textual information with consideration of products' type (Blanco et al., 2010).

In the context of e-commerce, interactive website design is critical to develop customers' better understanding and subsequently assure effective communication (Faisal et al., 2018). The welldesigned user interface in the e-commerce website can assist to solve customers' problems, eventually lead to sales improvement. For instance, a major retailer gained US $\$ 3,000,000$ increment in annual revenue by improving the usability of the e-commerce website (Spool, 2016). According to Manning et al. in 1998, the user-friendliness of e-commerce websites is important to increase customer satisfaction, emphasize the website uniqueness, enhance a brand and ultimately increase the market share. With simplicity and ease-of-use characteristic, it is easy for an ecommerce website to build customer loyalty (Najjar, 2011).

The essential principles of a good website design have been outlined which can be considered while developing a website (Pawar, 2018). These principles will help web designers to develop a website with enhancing usability. The principles include simplicity, consistency, typography and readability, mobile compatibility, imagery, easy loading, easy navigation and communication. Table 2 shows the explanations for each of the web design principles.

Simply put, one can develop an esthetical and functional website with keeping these principles. In addition, the five principles of persuasive web design introduced by Laja have been reviewed (Laja, 2019). Laja claimed that in the persuasion process, it is important to identify the target audience of a website. For example, the sales conversions of an e-commerce website can be increased with a 
better understanding of customer thoughts and their sub-conscious and emotional decision-making process. The persuasive web design principle from Laja includes clarity above all, visual appeals, strong visual hierarchy, conserve attention at all costs, and one action per screen. Table 3 explained each of the five persuasive web design principles provided an example of implementation.

Table 2: 8 Principles of Good Website Design

\begin{tabular}{ll}
\hline \hline Principle & Explanation \\
\hline Simplicity & $\begin{array}{l}\text { Clean and fresh design makes the website appeals to users, eliminate } \\
\text { elements on the web page avoid distraction of the users. }\end{array}$
\end{tabular}

Consistency $\quad$ Fonts sizes, headings, sub-headings font styles should be the same in the whole website to make users feel comfort and consistent.

Typography and Readability Using fonts that ease to read (avoid using too many different styles in the content)

Since users are searching for desired information, keep the typography on the website visually appealing and readable for users.

Mobile Compatibility

Due to the increasing usage of smartphones and tablets, the websites should have a responsive and adaptive design which suit all screen size.

\begin{tabular}{ll}
\hline Imagery & Choose a perfect colour combination to create a pleasing atmosphere \\
for users, keep enough white space to have a balanced look, avoid \\
multiple vibrant images.
\end{tabular}

Easy Loading

Shorten users waiting time by optimizing image size, combining and compress code into a central file for enhanced loading speed.

Easy Navigation

Design effective navigation by creating a logical page hierarchy. Follow "three-click-rule" so that users can get the desired information within 3 clicks.

Communication Ensure all the information in the website is well-organized in order to establish effortless communication with the users

Table 3: 5 Persuasive Web Design Principles

\begin{tabular}{|c|c|c|}
\hline Principle & Explanation & Example of implementation \\
\hline Clarity above all & $\begin{array}{l}\text { - A website should provide clear and } \\
\text { understandable content in every } \\
\text { single page. } \\
\text { - Key of the principle: Simple and } \\
\text { short statement with the use of } \\
\text { specific but not superlatives word, } \\
\text { together with a relevant image to } \\
\text { capture user's attention. }\end{array}$ & $\begin{array}{l}\text { Include a clear statement indicate the } \\
\text { products info and benefits to users, } \\
\text { together with a relevant image in the } \\
\text { homepage header. }\end{array}$ \\
\hline
\end{tabular}




\begin{tabular}{|c|c|c|}
\hline Visual appeal & $\begin{array}{l}\text { - low visual complexity - the simpler, } \\
\text { the better } \\
\text { - high 'prototypicality' -how } \\
\text { representative a design looks for a } \\
\text { certain category of websites }\end{array}$ & $\begin{array}{l}\text { In an E-Shop, there must be a shopping } \\
\text { cart, products category, or products } \\
\text { details which aligned with user's } \\
\text { expectation of an e-commerce site. }\end{array}$ \\
\hline $\begin{array}{l}\text { Strong visual } \\
\text { hierarchy }\end{array}$ & $\begin{array}{l}\text { A website should have a strong visual } \\
\text { hierarchy in order to draw user's } \\
\text { attention in those more important parts, } \\
\text { such as call to action. }\end{array}$ & $\begin{array}{l}\text { In e-commerce website, the products } \\
\text { always displayed on white background, } \\
\text { make the product itself looks prominent }\end{array}$ \\
\hline $\begin{array}{l}\text { Conserve } \\
\text { attention at all } \\
\text { costs }\end{array}$ & $\begin{array}{l}\text { - Use of contrast image, for example, } \\
\text { before and after, then and now. } \\
\text { - Novelty design }\end{array}$ & $\begin{array}{l}\text { The products on e-commerce always } \\
\text { displayed with image at first sight, } \\
\text { follow by short description, price and } \\
\text { rating. }\end{array}$ \\
\hline $\begin{array}{l}\text { One action per } \\
\text { screen }\end{array}$ & $\begin{array}{l}\text { - Clearly defined the most wanted } \\
\text { action for each page. } \\
\text { - Make it appear at opportune moment }\end{array}$ & $\begin{array}{l}\text { In e-commerce website, the "Shop } \\
\text { Now" button always showed up in the } \\
\text { home page header for ongoing } \\
\text { promotions. }\end{array}$ \\
\hline
\end{tabular}

The finding is in line with the results from previous studies where the importance of navigation design and information design were emphasized. In 2016, the relationship between website design and user engagement has been systematically reviewed. Seven effective and most frequent used website design elements have been shortlisted in the reviewed study which includes navigation, the importance of graphics and content utility (Garett et al., 2016).

\subsection{E-commerce in Malaysia: Lazada and Shopee}

In 2018, there were approximately 16.6 million e-commerce consumers in Malaysia (Malaysian Communications and Multimedia Commission, 2018). Compare to the global e-commerce giant like Amazon and Alibaba, Malaysians seems like preferable to the local e-commerce platform (Malaysian Communications and Multimedia Commission, 2018). Based on Economic Census 2018 by Department of Statistics Malaysia (2019), the income of e-commerce in Malaysia was dominated by local market with RM399.8 billion (89.3\%) compared to international market of RM41.3 billion (10.7\%). Dividing the e-commerce consumers into age groups gives a better picture of the Malaysian e-commerce market. Over $50 \%$ of the e-commerce consumers were adults aged 20 's $(36.2 \%)$ to 30 's $(36.0 \%)$. The older generations in Malaysia adopted to e-commerce is relatively low, only $15.3 \%$ of aged 40's and 6.3\% of aged 50's adopted to e-commerce in Malaysia. The "Map of E-Commerce" was created to identify the top e-commerce players in the country. The map reveal key insights for Malaysians by ranking the top 50 e-commerce players based on average quarterly traffic, social media followers, mobile application ranking, and number of staff (iPrice Insights, 2019). The data collected in July 2019 shows that the top 4 e-commerce marketplaces in Malaysia are Lazada, Shopee, Lelong, and Zalora (iPrice Insights, 2019).

Malaysia's e-commerce landscape has grown a lot since the inception of pioneer marketplaces like eBay Malaysia and Lelong. Lelong.my was the pioneer in e-commerce which had been in operation since 1999 (Lelong.my, 2019). This local e-commerce marketplace was founded by Interbase Resources Sdn Bhd (Lelong.my, 2019). Later in 2004, eBay was entered Malaysia market and 
become the leading player until 2012 (iPrice Insights, 2017). As online auction sites, both eBay and Lelong have established their unique customers base on the last decade (Wong, 2012). In 2012, Zalora and Lazada have launched in Malaysia, making the market more competitive. Within 2 years, Lazada has surpassed Lelong and eBay and turn out to be the most visited e-commerce website in Malaysia (iPrice Insights, 2017). It is worthy to study the success of Lazada and Shopee, which can overtake the pioneer and become the leading e-commerce players in Malaysia. As such, Lazada and Shopee have been selected as a case study for this research.

At present, Lazada is among the biggest e-commerce marketplace with the mobile-first Shopee trailing close behind. Lazada remained as the most searched e-commerce in Malaysia for 2018. However, the most competitive competitor of Lazada is Shopee. Shopee has closed the gap to Lazada by $47 \%$ in search interest in 2018 and becoming a serious competitor to Lazada. Figure 2 better illustrate the visitors of Lazada and Shopee from Malaysia and other SEA countries. The recent statistic shows that Lazada and Shopee were the most visited e-commerce platforms in Southeast Asia on desktop and mobile web (Chew, 2018a). In the last quarter of 2018 (Figure 2), companies with the highest average monthly visits on desktop and mobile web in Southeast Asia were Lazada (183.4 million visits), Tokopedia (153.6 million visits) and Shopee (147.6 million visits) (Chew, 2019). In first quarter of 2019, Lazada was visited by around 20.12 million users per month while 19.96 million users visited Shopee (Similar Web, 2019).

In less than a year, Shopee has experienced 302.9\% growth (Chew, 2018b), overtake 11street as the second most visited e-commerce site in Malaysia. Lazada and Shopee were highly active in organized flash sales events such as 11.11 Single's Day Sales, 7.7 Orange Madness, and other sales festival in conjunction with the celebration of Hari Raya. Both e-commerce merchants launched the sales events in an extravagant manner (DigitalNewsAsia, 2018). To overcome the delivery issues during peak hours, Shopee has improved delivery service by introduced Shopee 24 during 7.7 Orange Madness sales periods.

Figure 2: Number of Visitors of Lazada and Shopee

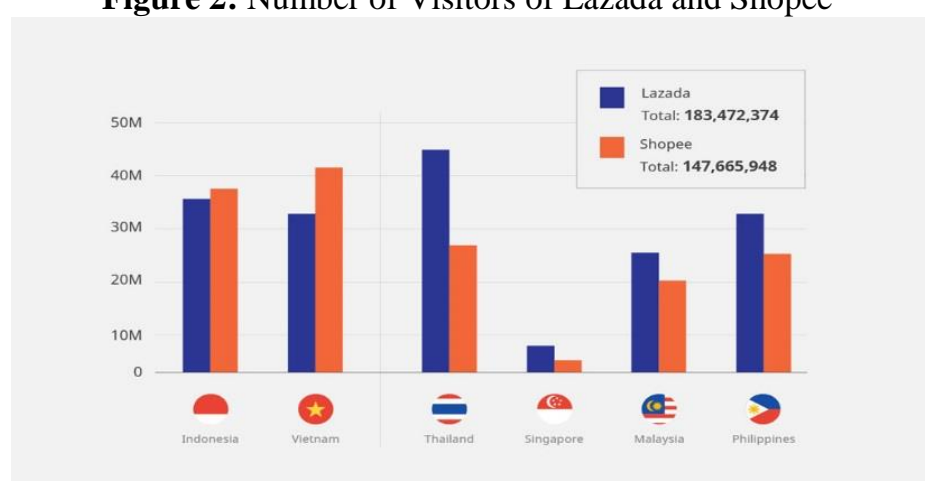

Lazada's e-commerce websites first soft launched in Malaysia in 2012. In just two years' time, Lazada has grabbed attention and rose to become Malaysia's most searched e-commerce. The experienced players such as Lelong and eBay have been overtaken in 2014. Two years after its founding, Rocket Internet raised about US\$814 million in funding the start-up which propel further 
growth and Lazada's popularity among Malaysians (Roy, 2018). In 2016, Alibaba Group bought controlling stake in Lazada to support Alibaba's expansion plans in Southeast Asia (Choudhury \& Kharpal, 2016). Today, Lazada still remained as the most popular online marketplace on desktop in Malaysia. Shopee was first launched in Malaysia in 2015. It has overtaken Zalora and Lelong and become Lazada's closest competitor within two years' time. This rapidly growing e-commerce was funded and founded by Forrest Li, CEO of SEA Group (formerly known as Garena). The team was highly experienced due to their background in online gaming and other internet consumer platforms (Roy, 2018). The unique strategy with prioritize mobile platform makes Shopee's rapid success. In 2014, Malaysia's mobile penetration was at $140 \%$. It is the highest in Southeast Asia (Teller, 2014) at that time. The launching of Shopee as mobile-first e-commerce was well-timed move. In Table 4, Lazada and Shopee has been compared from various aspects. These aspects include the web traffic, average visit duration (SiteGiant, 2018), global marketplace presence, Single's Day sale performance (Song, 2018), shipping fee, and uniqueness (WebShaper, 2017).

Table 4: Comparison of Lazada and Shopee

\begin{tabular}{lll}
\hline \hline Background & Lazada & Shopee \\
\hline & $\begin{array}{l}\text { A marketplace started by Rocket } \\
\text { Internet from German and currently } \\
\text { owned by Alibaba }\end{array}$ & $\begin{array}{l}\text { Mobile-first marketplace owned by } \\
\text { SEA group (formerly known as } \\
\text { Garena) }\end{array}$ \\
\hline $\begin{array}{l}\text { Average traffic } \\
\text { (Desktop and mobile } \\
\text { web only) }\end{array}$ & 31.2 million & 10.88 million \\
\hline Average visit duration & 6 minutes 41 seconds & 10 minutes 01 second \\
\hline $\begin{array}{l}\text { Global marketplace } \\
\text { presence }\end{array}$ & $\begin{array}{l}\text { Singapore, Thailand, Philippines, } \\
\text { Vietnam, Indonesia }\end{array}$ & $\begin{array}{l}\text { Singapore, Thailand, Philippines, } \\
\text { Vietnam, Indonesia, Taiwan }\end{array}$ \\
\hline $\begin{array}{l}\text { Singles Day Sale } \\
\text { performance }\end{array}$ & $\begin{array}{l}1.2 \text { million orders in the first hour } \\
11 \text { million orders in total }\end{array}$ \\
\hline Shipping Fee & $\begin{array}{l}\text { Sellers Pay for } 1^{\text {st }} \mathrm{kg} \text { Anything } \\
\text { exceeds 1 }{ }^{\text {st }} \mathrm{kg} \text { pays by buyers }\end{array}$ & Buyers pay \\
\hline \hline
\end{tabular}

\section{METHODOLOGY}

This study aims to evaluate the concise and representational successful e-commerce platforms in Malaysia. Two websites were selected based on monthly average traffic and ranked popularity in last 6 months. The most popular e-commerce websites in Malaysia is Lazada and Shopee with nearly 20 million visitors per month. This paper aims to evaluate the persuasion criteria of successful e-commerce websites by using the Persuasive System Design (PSD) model. This study is significant for local companies to learn from practice and analyse how the persuasive features could lead to success in e-commerce industry. The study is also important to analyse how such implementation could be enhanced and replicated to the local e-commerce website. The expert evaluation method was used to evaluate the online persuasion criteria on Lazada and Shopee. Three experienced (with more than 5 years experienced in e-commerce websites development) ecommerce website developers assess the website against a checklist. The checklist is developed according to the 28 persuasion features defined by Oinas-Kukkonen and Harjumaa in 2009. The checklist has been modified to suit the context of e-commerce (as presented in Table 1). The expert empirical evaluation was used to undergo regular tasks within chosen e-commerce websites. The 
website functionalities and usability have been checked according to the given definitions in the checklist. Each evaluator updated the results and reviews in Excel sheet against each persuasive feature in the checklist. Sever discussions have taken place to improve the preciseness of the results.

\section{RESULTS AND DISCUSSION}

A targeted literature review on PSD features in consumers' medication management information systems has been conducted in 2017, aimed to better understand the applicability of the PSD model (Win et al., 2017). The result of the study shows that tailoring was the most cited feature, followed by self-monitoring under this category (Win et al., 2017). The top 2 e-commerce website in Malaysia; Lazada and Shopee have been examined using PSD model. Table 5 shows the associated persuasive features in Lazada and Shopee accordingly. The four main categories of design technique are primary task support, dialogue support, credibility support and social support.

Table 5: Associated Persuasive Features in Lazada and Shopee

\begin{tabular}{|c|c|c|}
\hline Design Technique & Lazada & Shopee \\
\hline \multicolumn{3}{|l|}{ Primary Task Support } \\
\hline Reduction & $3.57 \%$ & $3.57 \%$ \\
\hline Tunnelling & $3.57 \%$ & $3.57 \%$ \\
\hline Tailoring & $3.57 \%$ & $3.57 \%$ \\
\hline Personalization & $3.57 \%$ & $3.57 \%$ \\
\hline Self-monitoring & $3.57 \%$ & $3.57 \%$ \\
\hline Simulation & $3.57 \%$ & $3.57 \%$ \\
\hline Rehearsal & $3.57 \%$ & $3.57 \%$ \\
\hline \multicolumn{3}{|l|}{ Dialogue Support } \\
\hline Praise & $0.00 \%$ & $3.57 \%$ \\
\hline Rewards & $3.57 \%$ & $3.57 \%$ \\
\hline Reminders & $3.57 \%$ & $3.57 \%$ \\
\hline Suggestion & $3.57 \%$ & $3.57 \%$ \\
\hline Similarity & $3.57 \%$ & $3.57 \%$ \\
\hline Liking & $3.57 \%$ & $3.57 \%$ \\
\hline Social role & $3.57 \%$ & $3.57 \%$ \\
\hline \multicolumn{3}{|l|}{ Credibility Support } \\
\hline Trustworthiness & $3.57 \%$ & $3.57 \%$ \\
\hline Expertise & $3.57 \%$ & $3.57 \%$ \\
\hline Surface credibility & $3.57 \%$ & $3.57 \%$ \\
\hline Real-world feel & $3.57 \%$ & $3.57 \%$ \\
\hline Authority & $0.00 \%$ & $0.00 \%$ \\
\hline Third-party endorsements & $3.57 \%$ & $0.00 \%$ \\
\hline Verifiability & $0.00 \%$ & $0.00 \%$ \\
\hline \multicolumn{3}{|l|}{ Social Support } \\
\hline Social Learning & $3.57 \%$ & $3.57 \%$ \\
\hline Social Comparison & $0.00 \%$ & $0.00 \%$ \\
\hline Normative influence & $3.57 \%$ & $3.57 \%$ \\
\hline Social facilitation & $0.00 \%$ & $0.00 \%$ \\
\hline
\end{tabular}




\begin{tabular}{lcc} 
Cooperation & $0.00 \%$ & $0.00 \%$ \\
Competition & $0.00 \%$ & $0.00 \%$ \\
Recognition & $0.00 \%$ & $0.00 \%$ \\
\hline Total & $\mathbf{7 1 . 4 3 \%}$ & $\mathbf{7 1 . 4 3 \%}$ \\
\hline \hline
\end{tabular}

The result shows that both e-commerce website has applied 71.43\% of the PSD principles. The most emphasize design technique in Lazada and Shopee is primary task support, followed by dialogue support. It is found that both Lazada and Shopee applied all principles under primary task support category. Online purchasing will cost an amount of money, it is crucial to increase user's ability by simplified the targeted behaviour. Prior study shows that personalisation was applied in $60 \%$ of successful e-commerce websites (Alhammad \& Gulliver, 2014). This feature enhanced the users shopping experience and uniqueness by offered personalised suggestions based on users' interests. Recently, Lazada further utilizes the primary task support feature by offering a new delivery option; allow users to pick up their parcel at their convenience (Song, 2019).

The previous study shows that dialogue support is most likely to influence online buying habit (Alhammad \& Gulliver, 2014; Abdul Hamid et al., 2019). In dialogue support category, Lazada has implemented all principles except "Praise", while Shopee has implemented all principles to the website design under this category. The persuasive design features under dialogue support such as rewards and reminders are efficient to enhance user's motivation. For instance, both Lazada and Shopee send a notification to remind users for discount vouchers redemption. According to the result, social support is the least selected persuasive features in both e-commerce website. Unlike the online auction website like Lelong and eBay, Lazada and Shopee provide non-competitive environment for online shoppers. Comparison, competition and recognition features under social support category are inappropriate to apply in such environment.

\subsection{Discussion}

The results suggest that persuasive technology features are extensively used and well implemented in successful e-commerce websites. This is in line with the findings on previous study (Alhammad \& Gulliver, 2014; Abdul Hamid et al., 2019). Result shows that both e-commerce website highly associated with the primary task support features. Fogg's Behavior Model suggests that increasing ability (making the behaviour simpler) is the path for increasing behaviour performance (Fogg, 1998). Primary task support features help to increase the shopper ability by making the target behaviour simpler and subsequently enhance the persuasiveness of the website (Oinas-Kukkonen \& Harjumaa, 2009). Simplified the checkout process is the most common way to allow shopper to complete the transaction in shorter time. The implementation of dialogue support features was found to be perfectly fit in with the nature of the virtual environment in online shopping platform (Alhammad \& Gulliver, 2014). With effective interaction, online traders can provide seamless shopping experience for shopper, which further enhance the real world feel as shopping at offline store. Therefore, website designers should emphasize on dialogue support features to increase the persuasiveness of the website.

As the e-commerce industry in Malaysia has been dominance by these two leading players, the local sellers must understand the implementation of persuasive features in Lazada and Shopee. There is a lack of thorough guidelines in implementing the persuasive features in e-commerce. Local companies are unable to compete with these two leading e-commerce players. The local 
sellers might perhaps get on better practices if they looked at the success of Lazada and Shopee as a benchmark. Thus, it is important to examine the persuasive design criteria in Lazada and Shopee using the PSD Model. This study focused on understanding the implementation of persuasive practices in e-commerce. However, an advanced analysis is needed to explore the efficient way of implementation for the e-commerce industry in Malaysia.

\section{CONCLUSION}

In this study, Lazada and Shopee were selected as case study based on the similarity, popularity, number of users, and the overall ranking. The study has examined online persuasion through ecommerce website by using Persuasive System Design (PSD) Model. Most of the persuasive features in this model has implemented in both e-commerce website. However, for research purposes, researchers need a theoretical framework to utilize the PSD model. Moreover, this study only focuses on evaluate the website design from developer point of view. In the context of ecommerce, user's perception on the persuasive features is crucial to rise users' satisfaction and consequently increase retailers' revenues. Hence, there is a necessity to assess the e-commerce website persuasiveness from user point of view.

Nevertheless, the evaluation of online persuasion criteria in this research is limited to desktop website. Further study can be carried out to examine the implementation of persuasive features in mobile application. However, this research proved that the success of the e-commerce websites is related with the implemented persuasive feature which can be manipulated and implemented by other e-commerce websites. The study provides a basic guideline to the local sellers of how and which persuasive feature that must be applied in the e-commerce website.

\section{ACKNOWLEDGEMENT}

This research was supported by Universiti Tun Hussein Onn Malaysia (UTHM) under GPPS (VOT number H327). We thank our colleagues from Faculty of Technology Management and Business (FPTP) who provided insight and expertise that greatly assisted the research, although they may not agree with all the interpretations/conclusions of this paper. We thank Assoc. Prof. Dr. Nor Aziati Binti Abdul Hamid from FPTP for assistance and comments that greatly improved the manuscript.

\section{REFERENCES}

Abdul Hamid, N. A., Cheun, C. H., Abdullah, N. H., Ahmad, M. F., \& Ngadiman, Y. (2019). Does Persuasive E-commerce Website Influence Users' Acceptance and Online Buying Behaviour? The Findings of the Largest E-commerce Website in Malaysia. In Y. Baghdadi, \& A. Harfouche (Eds.), ICT for a Better Life and a Better World: The Impact of Information and Communication Technologies on Organizations and Society (pp. 263-279). Springer.

Adaji, I., Oyibo, K., \& Vassileva, J. (2019). Effect of Shopping Value on the Susceptibility of ECommerce Shoppers to Persuasive Strategies and the Role of Gender. In H. OinasKukkonen, K. T. Win, E. Karapanos, \& E. Kyza (Eds.), Persuasive Technology: 
Development of Persuasive and Behavior Change Support Systems Lecture Notes in Computer Science (pp. 270-282). Springer.

Ajzen, I. (1991). The theory of planned behavior. Organizational Behavior and Human Decision Processes, 50(2), 179-211.

Aldenaini, N., Oyebode, O., Orji, R., \& Sampalli, S. (2020). Mobile Phone-Based Persuasive Technology for Physical Activity and Sedentary Behavior: A Systematic Review. Frontiers in Computer Science, 2, 19. https://doi.org/10.3389/fcomp.2020.00019

Alhammad, M. M., \& Gulliver, S. R. (2014, September 9-12). Online Persuasion for E-Commerce Websites. Proceedings of the 28th International BCS Human Computer Interaction Conference, Southport, UK, 264-269.

Altmeyer, M., Lessel, P., Muller, L., \& Krüger, A. (2019). Combining Behavior Change Intentions and User Types to Select Suitable Gamification Elements for Persuasive Fitness Systems. In H. Oinas-Kukkenon, K. T. Win, E. Karapanos, P. Karpinnen, \& E. Kyza (Eds.), Persuasive Technology: Development of Persuasive and Behavior Change Support Systems Lecture Notes in Computer Science (pp. 337-349). Springer.

Blanco, C. F., Sarasa, R. G., \& Sanclemente, C. O. (2010). Effects of visual and textual information in online product presentations: Looking for the best combination in website design. European Journal of Information Systems, 19(6), 668-686.

Chew, J. (2018a, December 19). E-Commerce Rewind 2018. Iprice. https://iprice.my/trends/insights/e-commerce-rewind-2018/

Chew, J. (2018b, May 03). A 10 Year History of eCommerce In Malaysia. https://www.valuewalk.com/2018/05/10-year-history-ecommerce-malaysia/

Chew, J. (2019, April 20). Top e-commerce platforms in 4Q18. The Borneo Post. https://www.theborneopost.com/2019/04/21/top-e-commerce-platforms-in-4q18/

Choudhury, S. R., \& Kharpal, A. (2016, April 12). Alibaba buys controlling stake in retailer Lazada. CNBC. https://www.cnbc.com/2016/04/12/alibaba-group-invests-1-billiondollars-in-lazada-group-and-eyes-southeast-asia.html

Connolly, D. (2000). A Little History of the World Wide Web. Webmaster. https://www.w3.org/History.html

DigitalNewsAsia. (2018, October 29). IPrice Group's Q3 2018 Map of E-Commerce indicates continual rise of Shopee and 11street. https:/www.digitalnewsasia.com/digitaleconomy/iprice-groups-q3-2018-map-e-commerce-indicates-continual-rise-shopee-and11 street

Department of Statistics Malaysia. (2019, May 14). For Statistics on Usage of ICT and ECommerce by Establishment 2018. [Press release]. https://www.dosm.gov.my/v1/index.php?r=column/pdfPrev\&id=U3FYOHJ3cE90UnNW MWdUaVMzRElKdz09

Garett, R., Chiu, J., Zhang, L., \& Young, S. D. (2016). A Literature Review: Website Design and User Engagement. Online Journal Communication Media Technology, 6(3), 1-14.

Faisal, C. M. N., de Andres-Suarez, J., Gonzalez-Rodriguez, M., Fernandez-Lanvin, D., Ahmad, M., \& Habib, M. A. (2018). Impact of web design features on irritation for E-commerce websites. SAC 2018: Proceedings of the 33 $3^{\text {rd }}$ Annual ACM Symposium on Applied Computing, 656-663.

Fishbein, M., \& Ajzen, I. (1977). Belief, attitude, intention, and behavior: An introduction to theory and research. Reading, MA: Addison-Wesley.

Fogg, B. (1998). Persuasive computers: Perspectives and research directions. Proceedings of the SIGCHI Conference on Human Factors in Computing Systems - CHI 98, 225-232. 
Fogg, B. J., Soohoo, C., Danielson, D. R., Marable, L., Stanford, J., \& Tauber, E. R. (2003). How do users evaluate the credibility of websites? Proceedings of the 2003 Conference on Designing for User Experiences - DUX 03. doi:10.1145/997078.997097

Gass, R. H., \& Seiter, J. S. (2011). Persuasion, social influence, and compliance gaining. Boston: Allyn \& Bacon.

iPrice Insights. (2017). The History of E-Commerce in Malaysia - iPrice Malaysia. https://iprice.my/insights/history-of-ecommerce-malaysia/

iPrice Insights. (2019). The Map of E-commerce in Malaysia. https://iprice.my/insights/mapofecommerce/en/

Kaptein, M., \& Duplinsky, S. (2013). Combining multiple influence strategies to increase consumer compliance. International Journal of Internet Marketing and Advertising, 8(1), 32-5. https://doi.org/10.1504/IJIMA.2013.056586

Laja, P. (2019, July 15). 5 Principles of Persuasive Web Design. CXL. https://conversionxl.com/blog/5-principles-of-persuasive-web-design/

Lehto, T., \& Oinas-Kukkonen, H. (2015). Examining the Persuasive Potential of Web-based Health Behavior Change Support Systems. AIS Transactions on Human-Computer Interaction, 7(3), 126-140.

Lelong.my (2019). About Lelong.my Malaysia: History \& Background. https://www.lelong.com.my/content/help/AboutLelong

Locke, E. A. (1987). [Review of the book Social Foundations of Thought and Action: A SocialCognitive View, by A. Bandura]. The Academy of Management Review, 12(1), 169-171.

Manning, H., McCarthy, J. C., \& Souza, R. K. (1998). Why most Web sites fail. Interactive technology strategies: Forrester Research, 3(7), September.

Matthews, J., Win, K. T., Oinas-Kukkonen, H., \& Freeman, M. (2016). Persuasive Technology in Mobile Applications Promoting Physical Activity: A Systematic Review. Journal of Medical Systems, 40(3), 72. https://doi.org/10.1007/s10916-015-0425-X

McDowell, W. C., Wilson, R. C., \& Kile, C. O. (2016). An examination of retail website design and conversion rate. Journal of Business Research, 69(11), 4837-4842.

Malaysian Communications and Multimedia Commission. (2018). E-Commerce Consumers Survey 2018. https://www.mcmc.gov.my/skmmgovmy/media/general/pdf/ecs-2018.pdf

Najjar, L. J. (2011). Designing E-Commerce User Interfaces. In K-P. L. Vu, \& R. W. Proctor (Eds.), Human Factors and Ergonomics Handbook of Human Factors in Web Design (2 ${ }^{\text {nd }}$ ed, pp. 587-598). CRC Press.

Oduor, M., \& Oinas-Kukkonen, H. (2019). Committing to change: A persuasive systems design analysis of user commitments for a behaviour change support system. Behaviour \& Information Technology, 40(1), 20-38.

Oinas-Kukkonen, H., \& Harjumaa, M. (2008). A Systematic Framework for Designing and Evaluating Persuasive Systems. In H. Oinas-Kukkonen, P. Hasle, M. Harjumaa, K. Segerstahl, \& P. Ohrstrom (Eds.), Persuasive Technology: Third International Conference, Persuasive 2008 Proceedings (pp. 164-176). Springer-Verlag Berlin Heidelberg.

Oinas-Kukkonen, H., \& Harjumaa, M. (2009). Persuasive Systems Design: Key Issues, Process Model, and System Features. Communications of the Association for Information Systems, 24(1), 485-500.

Pawar, S. (2021, May 21). 8 Principles of Good Website Design. ASTRA. https://wpastra.com/good-website-design/

Petty, R. E., \& Cacioppo, J. T. (1981). Attitude and persuasion: Classic and contemporary approaches. Dubuque, IA: Wm. C. Brown Company. 
Radomski, A. D., Wozney, L., Mcgrath, P., Huguet, A., Hartling, L., Dyson, M. P., Bennett, K. J., \& Newton, A. S. (2019). Potential Reduction of Symptoms With the Use of Persuasive Systems Design Features in Internet-Based Cognitive Behavioral Therapy Programs for Children and Adolescents With Anxiety: A Realist Synthesis. JMIR Mental Health, 6(10). e13807

Raggett, D., Alexander, I., \& Lam, J. (1996). HTML 3: Electronic publishing on the World Wide Web. Harlow: Addison-Wesley.

Roy, S. (2018, July 31). The history of e-commerce in Malaysia. Tech Wire Asia. https://techwireasia.com/2018/07/the-history-of-e-commerce-in-malaysia/

Similar Web. (2019). Traffic Statistics - Comparison between Shopee and Lazada. https://www.similarweb.com/website/lazada.com.my/?competitors=shopee.com.my

SiteGiant. (2018). Malaysia Marketplace Comparison - Lazada, Shopee, 11Street, Lelong \& Qoo10. https://www.sitegiant.my/malaysia-marketplace-comparison/

Song, O. (2018, November 21). How Did Lazada, Shopee, \& 11street Perform On 11.11 Singles Day 2018? Ringgit Plus. https://ringgitplus.com/en/blog/Online-Shopping/How-DidLazada-Shopee-11street-Perform-On-11-11-Singles-Day-2018.html

Song, O. (2019, Mar 29). Lazada Malaysia Introduces New Collection Point Feature for SelfPickup. Ringgit Plus. https://ringgitplus.com/en/blog/Online-Shopping/Lazada-MalaysiaIntroduces-New-Collection-Point-Feature-For-Self-Pickup.html

Spool, J. (2016, February 1). The $\$ 300$ Million Button. Linkedin. https://www.linkedin.com/pulse/300-million-button-jared-spool

Teller, S. (2014, February). Mobile Malaysia: Ahead of the Pack. On Device Research. https://ondeviceresearch.com/blog/mobile-malaysia-internet-mobile-ecommerce-trends

Thielsch, M. T., Blotenberg, I., \& Jaron, R. (2014). User evaluation of websites: From first impression to recommendation. Interacting with Computers, 26(1), 89-102.

WebShaper. (2017). Compare Malaysia eCommerce Marketplaces. https://www.webshaper.com.my/compare-ecommerce-marketplaces/

Win, K. T., Mullan, J., Howard, S., \& Oinas-Kukkonen, H. (2017). Persuasive Systems Design features in Promoting Medication Management for consumers. Proceedings of the 50th Hawaii International Conference on System Sciences, 3326-3335. https://doi.org/10.24251/hicss.2017.403

Win, K. T., Roberts, M. R., \& Oinas-Kukkonen, H. (2018). Persuasive system features in computer-mediated lifestyle modification interventions for physical activity. Informatics for Health and Social Care, 44(4), 376-404.

Winn, W. \& Beck, K. (2002). The persuasive power of design elements on an e-commerce web site. Technical Communication, 49, 17-35.

Wolf, M. (2014, September). Shaping Globalization. Finance \& Development, 51(3), $22-25$. https://www.relooney.com/NS4053/00_NS4053_148.pdf

Wong, J. (2012, October 7). The evolution of e-commerce to social commerce. The Borneo Post. https://www.theborneopost.com/2012/10/07/the-evolution-of-e-commerce-to-socialcommerce/2/ 